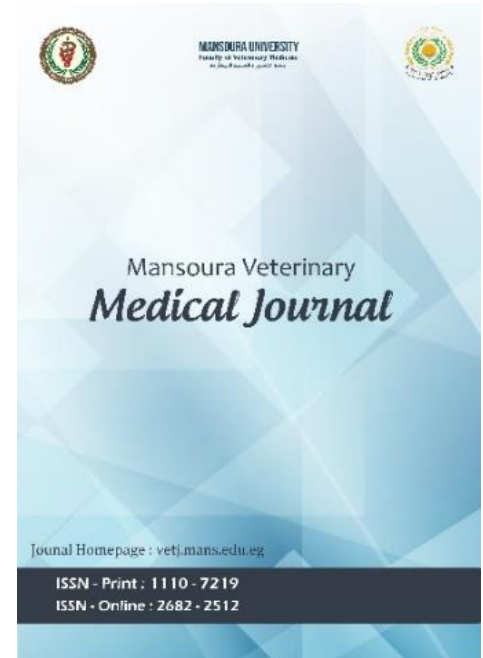

\title{
The effects of oral ketoconazole and griseofulvin on the fertility of male rabbits
}

Amal Mohamad, Aza Hassan, Magdy Amer, El-Said Abdel-Aziz

To cite this article: Amal Mohamad, Aza Hassan, Magdy Amer, El-Said AbdelAziz. The effects of oral ketoconazole and griseofulvin on the fertility of male rabbits. Mansoura Veterinary Medical Journal 2020; 21, 2: 32-38.

To link to this article: https://doi.org/10.35943/mvmj.2020.21.2.0203

Published online: 25 June 2020

Submit your article to this journal 


\title{
The effects of oral ketoconazole and griseofulvin on the fertility of male rabbits
}

\author{
Amal Mohamad ${ }^{1 *}$, Aza Hassan ${ }^{1}$, Magdy Amer $^{2}$, El-Said Abdel-Aziz ${ }^{3}$ \\ ${ }^{1}$ Animal Health Research Institute, Mansoura, Egypt \\ ${ }^{2}$ Department of Pharmacology, Faculty of Veterinary Medicine, Mansoura University, Mansoura, P.0 35516, Egypt \\ ${ }^{3}$ Department of Pharmacology, Faculty of Veterinary Medicine, Zagazig University, Egypt
}

ARTICLE HISTORY

Received: 21.12.2019

Revised: 17.05 .2020

Accepted: 18.05 .2020

Address correspondence to Amal Mohamed; Tel: +201208652860; E-mail: amal2325764@yahoo.com

\section{ABSTRACT}

\begin{abstract}
Objectives: To investigate possible side effects of ketoconazole and griseofulvin on fertility of clinically healthy male rabbits.

Design: Randomized controlled experimental study.

Animals: Thirty mature male rabbits.

Procedures: Rabbits were randomly allocated into three equal sized groups (10 a nimals each). The first group served as a control group (received no treatment), the second group received griseofulvin $(25 \mathrm{mg} / \mathrm{kg}$ B.W) orally for 30 days, and the third group received ketoconazole $(50 \mathrm{mg} / \mathrm{kg}$ B.W) orally for 30 days. Semen samples were colle cted after 1 day, 1 week and 2 weeks post-administration to determine sperm motility, \% of live and dead sperms, total sperm abnormalities and sperm cell concentration. Two weeks post-administration, testes and epididymides were removed for histopathological examination.

Results: Both drugs produced a significant reduction in the serum testosterone level, sperm cell concentration, percent of live sperms and percent of sperm motility.

Conclusion and clinical relevance: Ketoconazole and grise ofulvin have a ne gative impact on fertility of male rabbits, and the effect is more pronounced with ketoconazole.

Keywords: Ketoconazole, Griseofulvin, Fertility, Rabbit
\end{abstract}

\section{INTRODUCTION}

Rabbit is an excellent laboratory animal that offers many advantages in the field of reproduction [1]. Rabbit farming is a promising and developing industry that can have a positive impact on national economy in Egypt. Considerable efforts have been done in epidemiological studies to highlight the nature of rabbit diseases and the control measures, and to immediately plan for national surveys of the current rabbit problems [2].

Reproduction is considered an important part for production process, therefore any drop in animal fertility can lead to economic losses in animal production [3]. Fertility is defined as the ability of a cyclic animal to establish pregnancy and is maintained by breeding goodmanaged female using high-quality semen that is introduced into the female genital tract at the appropriate time. Each male should have a good reproductive performance and a superior genetic profile as the male fertility and genetic value a ppears more important than those of the female [4].

The exposure of males to some drugs and chemicals may affect their sexual functions. Some drugs can damage spermatogonia cells that represent the male genome, and so disturb the spermatozoid under maturation [5]. The fungal diseases are considered a serious hazard for human and a nimal health. Fungal infections can cause allergy due to fungal proteins, toxicity due to mycotoxins found in fungi. Many fungal infections are caused by opportunistic pathogens that may be endogenous (e.g. Candida infections) or are acquired from the environment (e.g. Cryptococcus, Aspergillus infections) [6].

Griseofulvin is one of the most selective antifungal inhibitory agents. It has an effect against many fungi. Griseofulvin acts by interfering with the intracellular microtubule production and thus inhibits fungal mitosis. The selective toxicity of griseoful vin for fungi and its spectrum of action is restricted to the dermatophyte fungi mainly (causes of ringworm and a thlete's foot)[6].

Ketoconazole is a member of imidazole family which has a broad-spectrum antifungal activity. It is considered the gold standard among the azol e derivative antifungal drugs. It has proven to be the most successful and most widely used a ntifungal azole-derivative to date [7].

The aim of this study was to investigate the effect of ketoconazole and griseofulvin on the reproductive performance of male rabbits through the assessment of serum testosterone level and semen quality as well as the histopathological effect on testes and epididymis of rabbits. 


\section{MATERIALS AND METHODS}

\subsection{Animals}

This study was performed on 30 clinically healthy New Zealand rabbits with an average age of 5-6 months and average weight of $3.5 \pm 0.5 \mathrm{~kg}$. Animals were apparently heal thy with normal external genitalia. The animals were randomly divided into three equal groups, each of 10 rabbits. Group (1) was kept as a control and received no treatment. Group (2) was given griseofulvin as a solution orally (Griseofulvin, Glaxo Laboratories, white to creamy- or yellowish-white, crystalline powder) [8] at a dose of 25 $\mathrm{mg} / \mathrm{kg}$ once daily for 30 days [9]. Group (3) was given Ketoconazol eas a solution (El Nile pharmaceutical Company, Cairo, Egypt) to rabbits orally at a dose of $50 \mathrm{mg} / \mathrm{kg} / \mathrm{day}$ for 30 days [10]. The experimental protocol of this work was approved by the Research Ethics Committee of the Faculty of Veterinary Medicine, Mansoura University.

\subsection{Collection of Samples}

Semen and blood samples were collected from each animal at 31,38 and 45 days of initial administration. Serum was us ed for assaying the testosteronelevel. The semen was collected by means of an artificial vagina filled with a warm liquid (about $45^{\circ} \mathrm{C}$ ). A doe was fitted with this device and presented to the buck. Some authors reported that previous stimulation of the buck increases sperm concentration, and that leaving a doe on the top of the buck's cage for several minutes may help in stimulating bucks. The collected semen samples were used for the determination of sperm characterizations including the following:

\subsubsection{Serum testosterone level}

Serum testosterone levels were meas ured according to the method described by Castro et al. [13].

\subsubsection{Sperm motility}

The semen was initially diluted with warm sodiumcitrate solution $2.9 \%$ and the sperm motility was assessed according to the method described previously [11].

\subsubsection{Percentage of live and dead sperms}

The percentages of dead sperms were measured accordingto Parker and McDaniel [11].

\subsubsection{Percentage of total sperm abnormalities}

The percentages of morphologically abnormal sperms were measured according to the method described previously [11].

\subsubsection{Sperm cell concentration}

Sperm cell concentration was determined using hemocytometer and the number of sperm $/ \mathrm{mL}$ was calculated according to the method described by Habeeb et al. [12].

\subsection{Histopathological analysis}

Two weeks from the administration of the last dose of the drugs, tissue samples (testes and epididymis) were removed and immersed immediately in $10 \%$ buffered formalin for histopathological examination [14].

\subsection{Statistical analysis}

Data were statistically analyzed using Statistical Package of Social Sciences (SPSS), Version 17 (Inc., Chicago, IL, USA) computer software. Data were expressed as mean \pm SE. The effects of treatment on each variable measured were analyzed using general linear model repeated measures ANOVA [15]. When there is a significant result, one-way ANOVA with post hoc Duncan multiple comparison tests were used to detect the specific variations and the level of significance was set at $\mathrm{P}<0.05$ [16].

\section{RESULTS}

\subsection{Serum testosterone level}

The effect of oral administration of griseofulvin and ketoconazole 30 consecutive days on the serum level of testosterone hormone in rabbits is presented in figure (1). Results revealed a significant a decline in total serum testosterone hormone level in treated groups along the whole experimental period $(P<0.05)$ in comparison to the control group (Figure 1). Both griseofulvin and ketoconazoletreated groups induced a significant decrease $(P<0.05)$ in total serum testosterone level at 31 days $(0.89 \pm 0.24$ and $0.80 \pm 0.24$ respectively) post-dosing. The level of serum testosterone then increased in 38 day and in 45 day postadministrations compared to that of 31 day in all groups however the increase was not significant (Figure 1).

\subsection{Semen picture}

\subsubsection{Semen volume}

The effect oral administration of griseofulvin and ketoconazole on semen volume in rabbits is presented in figure (2). There was a significant decline $(P<0.05)$ in semen volume in treated groups along the whole experimental period in comparison to the control group (Figure 2). Both griseofulvin and ketoconazole-treated groups showed a significant decrease $(P<0.05)$ in semen volume at 31 day $(0.75 \pm 0.14$ and $0.3 \pm 0.1$ respectively), 38 day $(1.2 \pm 0.14$ and respectively) and at 45 day $(1.2 \pm 0.2$ and $1.3 \pm 0.13$ res pectively) post-dosing. The semen volume then increased in 38 day and in 45 day post-administrations in all groups compared to that of 31 day however the increase was not significant (Figure 2). 


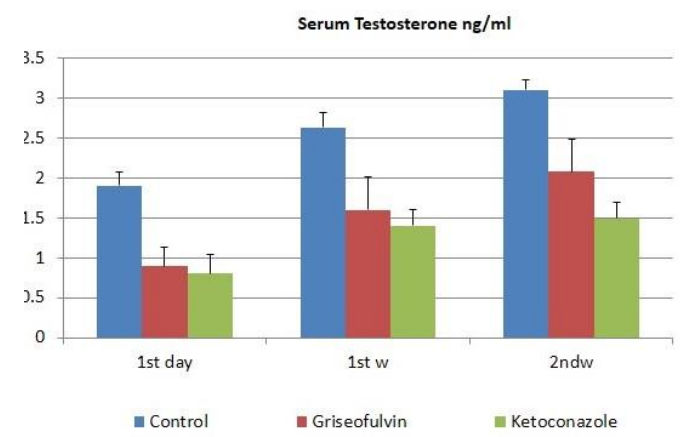

Figure 1. Effect of oral administration of grise ofulvin and ketoconazole on serum testosterone levels in rabbits.

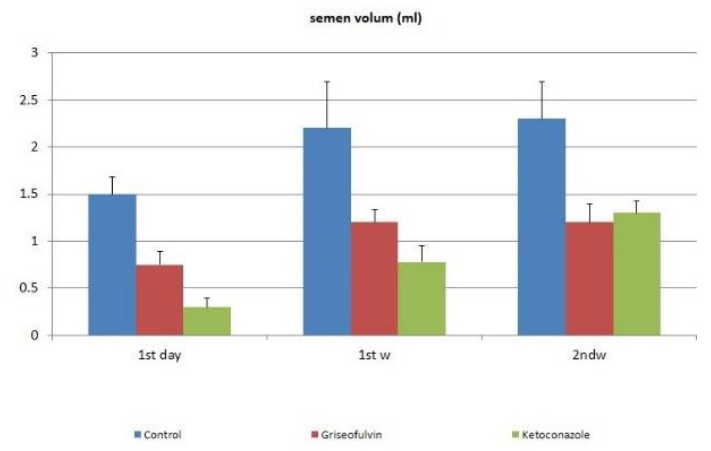

Figure 2. Effect of oral administration of grise ofulvin and ketoconazole on semen volume in rabbits.

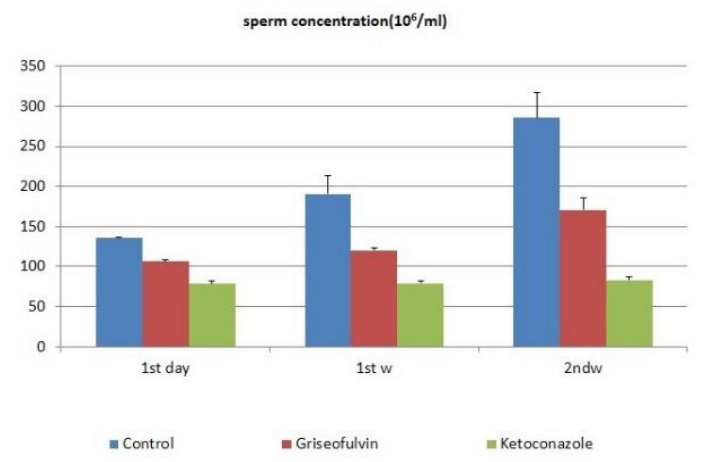

Figure 3. Effect of oral administration of grise ofulvin and ketoconazole on sperm motility in rabbits.

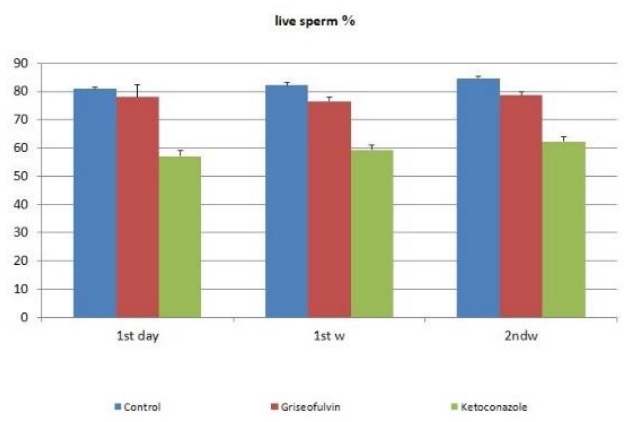

Figure 4. Effect of ora l admin istration of g riseofulvin and ketoconazole on total sperm abnormalities in rabbits.

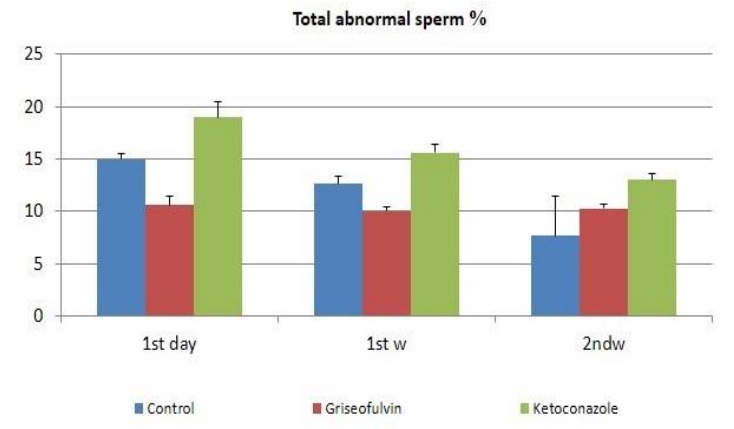

Figure 5. Effect of oral administration of grise ofulvin and ketoconazole on sperm cell concentration in rabbits.

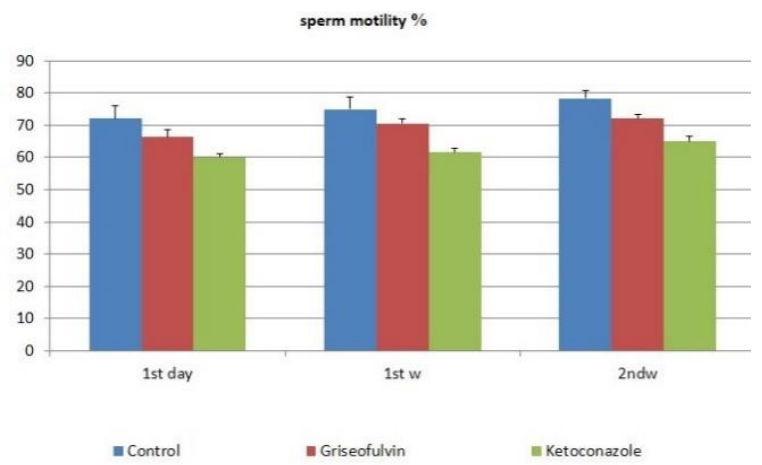

Figure 6. Effect of oral administration of grise ofulvin and ketoconazole on live sperms in rabbits.

\subsubsection{Sperm motility}

The effect of oral administration of gris eofulvin and ketoconazole on sperm motility in rabbits is presented in figure (3). The therapeutic dose of griseofulvin did not alter the percent of sperm motility at 31 day, 38 day and 45 day post stop-dosing compared to the control group $(66.3 \pm 2.3$, $70.6 \pm 1.4$ and $72 \pm 1.5$ respectively). On the other hand, ketoconazole produced a significant decrease in the percent of sperm motility $(\mathrm{P}<0.05)$ at 31 day, 38 day and at 45 day post-dosing compared with control group $(60 \pm 1.1,61.6 \pm$ 1.2 and $65 \pm 1.5$ respectively) (Figure 3 ).

\subsubsection{Percent of total sperm abnormalities}

The effect of oral administration of griseofulvin and ketoconazole on total sperm abnormalities in rabbits is presented in figure (4). Results showed a significant reduction in the percent of total sperm abnormalities $(P<0.05)$ in griseofulvin-treated group in 31 day post-dosing compared to the control group (10.6 \pm 0.8 and $15 \pm 0.5$ respectively), while after 38 day and at 45 day post-dosing $(10 \pm 0.5$ and $10.3 \pm 0.33$ respectively) this effect disappeared compared to the control group (12.6 \pm 0.8 and $7.7 \pm 3.8$, respectively). Meanwhile, the administration of ketoconazole produced a significant increase in the percentage of total spermabnormalities $(P<$ 0.05 ) in 31 day, 38 day and 45 day post-dosing ( $19 \pm 1.5$, $15.6 \pm 0.8$ and $13 \pm 0.57$ respectively), compared to control group ( $15 \pm 0.5,12.6 \pm 0.8$ and $7.7 \pm 3.8$, res pectively) (Figure $4)$. 


\subsubsection{Sperm cell concentration}

The effect of oral administration of griseofulvin and ketoconazole on sperm cell concentration in rabbits is presented in figure (5). Griseofulvin caused a significant decrease in sperm cell concentration $(P<0.05)$ at 31 day, 38 day and 45 day post-dosing $(106 \pm 3.0,120 \pm 2.8$ and $170.6 \pm$ 15 respectively). Similarly, ketoconazole induced a significant reduction $(P<0.05)$ in sperm cell concentration in 31 day, 38 day and 45 day post-dosing $(78 \pm 3.6,79 \pm 3.5$ and $83.3 \pm 4.1$ respectively) post-administration compared to the control group $(136.3 \pm 0.6,190.9 \pm 22.9$ and $285.6 \pm$ 31 respectively) (Figure 5).

\subsubsection{Percentage of live sperms}

The effect of oral administration of griseofulvin and ketoconazole for 30 consecutive days on percentage of live sperms in rabbits is presented in figure (6). Results revealed a non-significant reduction in the percentage of live sperms in griseofulvin-treated groups at 31day post-a dministration, however the reduction was significant $(P<0.05)$ in the 38 day and at 45 day $(76.6 \pm 1.2$ and $78.6 \pm 1.4$ respectively) post-dosing compared to the control group $(82.3 \pm 0.8$ and $84.6 \pm 0.8$ respectively). The therapeutic dose of ketoconazole evoked a significant reduction $(P<0.05)$ in the percent of live sperms at 31 day, 38 day and at 45 day postadministration $(57 \pm 2.08,59.3 \pm 1.7$ and $62.3 \pm 1.7$ respectively) compared to the control group ( $81 \pm 0.5,82.3 \pm$ 0.8 and $84.6 \pm 0.8$ res pectively) (Figure 6 ).

\subsection{Histopathological findings}

\subsubsection{Testes lesions}
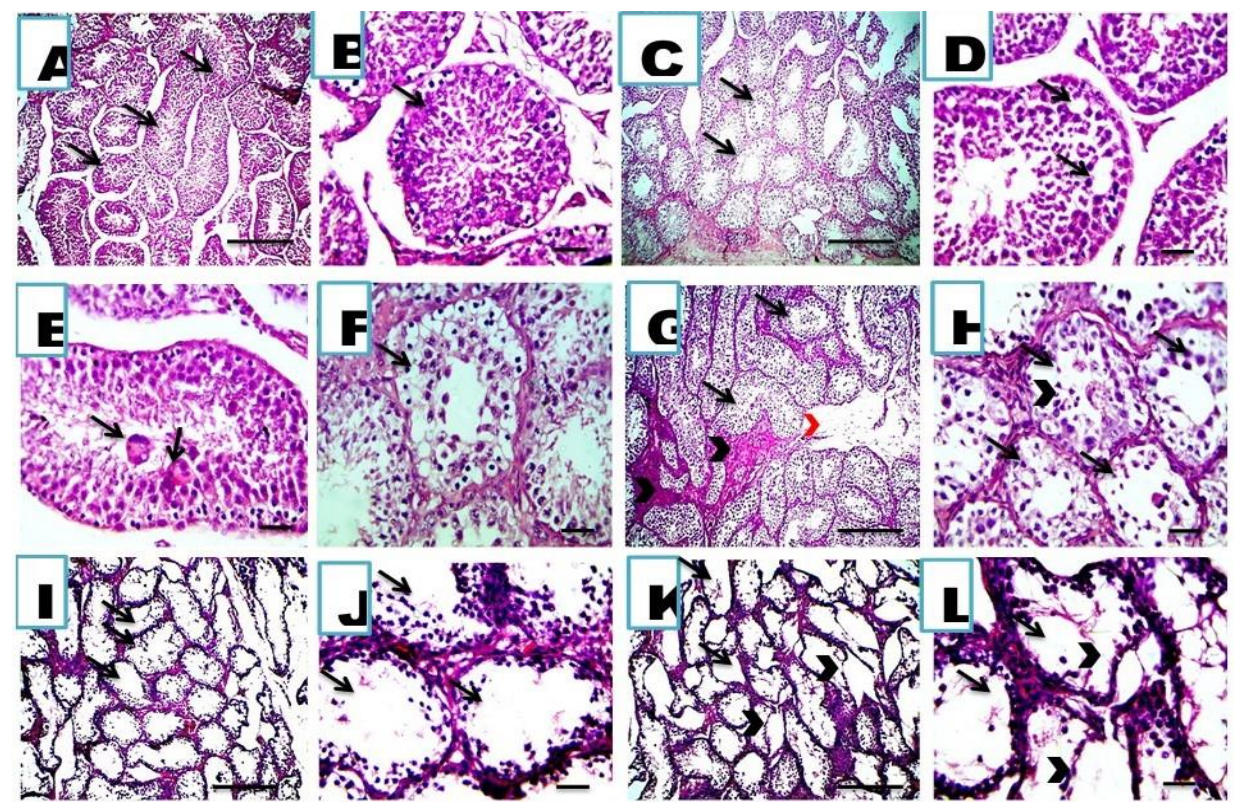

Figure 7. Testes sections showing normal histology of sem inife rous tubules (black arrows) in control group (A \& B), from mild changes cha racterized by vacuolar degeneration in spermatocytes (black arrows) (C \& D) and spermatocytes' giant cells (black arrows) (E) to mode rate tubular degeneration (black arrows) (F) in ketoconazole-treated group, marked interstitial fibrosis (black arrowhead) and edema (red arrow) (G) with severe tubular degenera tion (black arrows) and desquamation of germ cells in lumen (black arrowheads) $(\mathrm{H})$, arrested spermatogenesis cha racte rized by wide lumen of tubules, few germ cells and spermatocytes lining tubules with absence of sperms (black arrows) (I \& J) or characte rized by wide lumen of tubules lined by few germ cells with absence of spermatocytes and sperms (black arrows) in addition to separation of germ cell layer from basement membrane (black arrow) (K \& $L$ ) in griseofulvin-treated group. $H \& E, X: 100$ bar $100(A, C, G, I, K)$ and X: 400 bar 50 (B, D, E, F, H, J, L). 

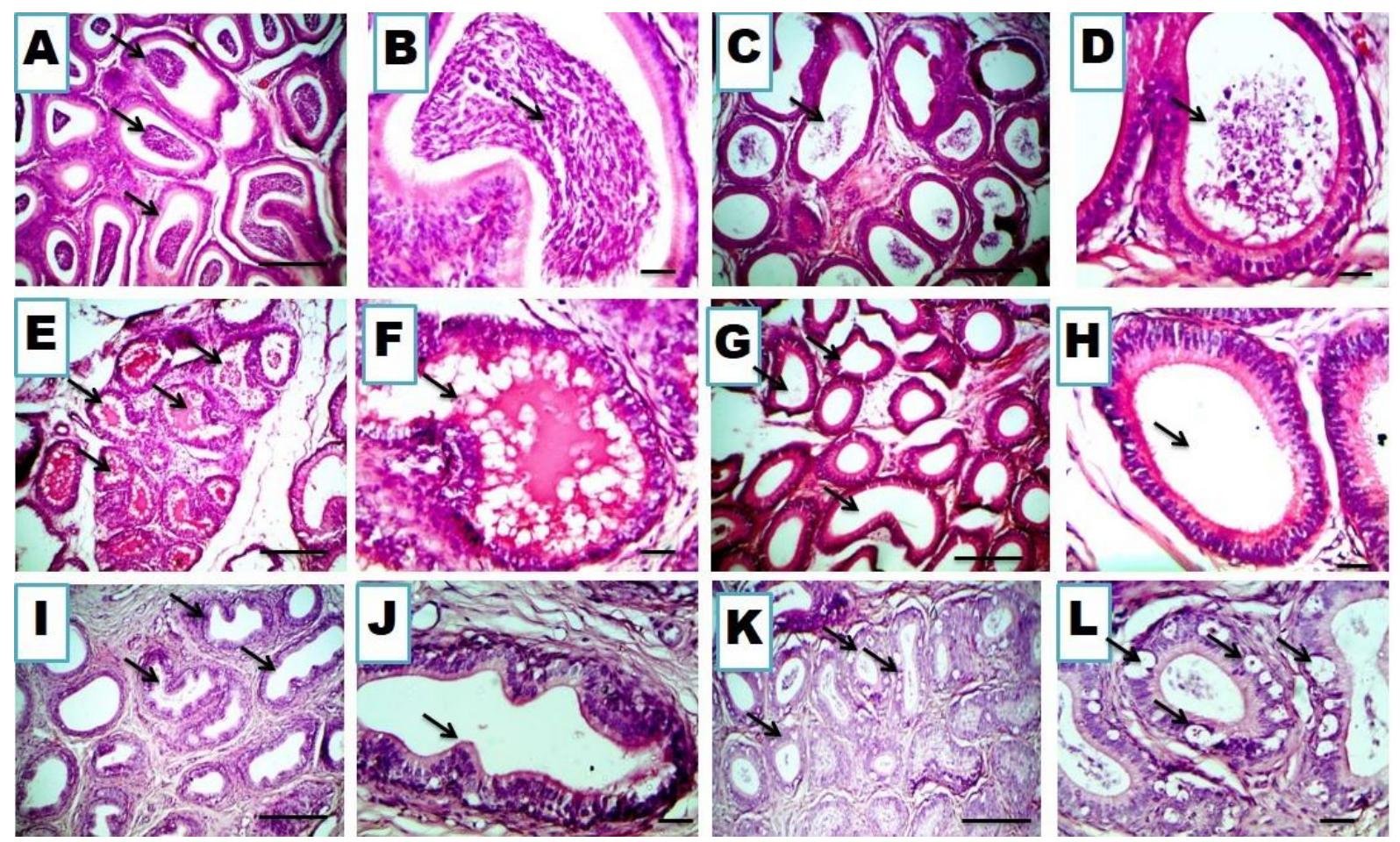

Figure 8. Epididymis shows normal histology of ducts with great quantity of sperms (black arrows) in control group (A \& B), few sperms with large amount of exfoliated germ cells (black arrows) (C \& D) from ducts in ketoconazole treated group, severe changes in griseofulvin-treated group characterized by hyalinization of sperms in lumen of ducts (black a rrows) (E \& F), absence of sperms (black arrows) (G \& H), blabbing of epithelial lining ducts (black arrowheads) (I \& J) and vacuolization of epithelial lining ducts (black arrow) (K \& L). H \& E, X: 100 bar 100 (A, C, E, G, I, K) and X: 400 bar 50 (B, D, F, H, J, L).

\section{DISCUSSION}

Infertility is considered as a real challenge to animal production. Several factors can affect the production and quality of sperms including drugs, toxins and environmental factors [17]. Antifungal agents are widely us ed in veterinary practice. They are playing an important role in the control and treatment of fungal diseases in different animals [18].

In the current study, oral administration of gris eofulvin and ketoconazole reduced serum testosterone levels in rabbits at all tested time points. The histopathological changes induced by the drugs support the biochemical finding. Similar finding has reported that administration of griseofulvin evokes necrosis in the seminal vesicle and minimized the output of the sperm in rats [21]. In another study, it was shown that gris eofulvin induced oligos permia in sheep [22] and elicited adverse effects on sperms of mice [23]. In the same line, gris eofulvin has been found to affect the germ cells of male mice and to reduce the serum level of testosterone [28]. Similarly, ketoconazole has been shown to block testosterone biosynthesis in rat Leydig cells [24], and to induce a transient decrease in the level of serum testosterone in human [25]. Administration of ketoconazole has also been reported to induce a significant reduction in the level of serum testosterone in male rats $[19,26,27]$. In addition, a testicular da mage and reduced testos teronelevel in serum of ketoconazole-treated males has also been reported [29].
The results of the present study also demonstrated a marked decrease in semen volume, sperms concentration, percent of live sperms and percent of sperm motility and an increase in the morphol ogically abnormal sperms of rabbits treated with griseofulvin and ketoconazole at all-time points. Administration of gris eofulvin has been reported to increase the abnormalities of sperm in mice $[9,32]$ and rabbit [33]. On the other hand, fluconazole has been shown to decrease sperm cells motility and progressivity [34]. High doses of griseofulvin have been shown to cause a deterioration of frozen semen quality [22]. It has been reported that ketoconazole had a spermicidal action if mixed with ejaculated sperm (in vitro) obtained from dogs, monkeys and humans [30]. Furthermore, Drobnis and Nangia [31] stated that oral administration of ketoconazole could induce inhibition in cauda epididymal sperm motility post-dosing and arrest in the epididymal spermatozoa motility.

In the current study, griseoful vin elicited mild changes in the testes and epididymis particularly at the 45 day of supplementation.These results agree with those obtained previously. It has been shown that the use of griseofulvin in rats induced necrosis and damage in the seminal epithelium reducing total sperm output [21]. Similarly, gris eofulvin has been reported to have a genotoxic effect on both male and female germ cells [28]. In addition, Amin et al [26] demonstrated that ketoconazole induced severe testicular histopathological lesions such as degeneration of the seminiferous tubules and depletion of germ cells. On other 
hand, lamsaard et al. [35] stated that the seminiferous tubules of ketoconazole-treated mice showed sloughing of germ cells and earlycell degeneration.

\section{Conclusion}

Oral daily administration of griseofulvin and ketoconazole for 30 consecutive days has a negative impact on male rabbit fertility.

\section{Conflict of interest statement}

The authors declare that there is no conflict of interest in the current research work.

\section{Research Ethics Committee Permission}

The current research work was conducted according to standards of Research Ethics committee, Faculty of Veterinary Medicine, Mansoura University.

\section{Authors' contribution}

A. M. and M. A. conducted the experiment, the analytical procedures, and wrote the manuscript, $A$. M. designed the experiment, and revised the manuscript, $M$. A. revised the manuscript.

\section{REFERENCES}

[1] Naughton CK, Nelson DR, Thomas JR AJ. Development of an inexpens ive artificial vagina for semen collection from rabbits. J. Androl 2003;24:712-5. https://doi.org/10.1002/j.1939-4640.2003.tb02731.x

[2] Mohammed HA, Eid A, El-Bakrey RM. A review of rabbit diseases in Egypt. WARTAZOA Indonesian. Am J Anim Vet Sci 2013;23. https://doi.org/10.14334/wartazoa.v23i4.1009

[3] Verma O, Kumar R, Kumar A, Chand S. Assisted Reproductive Techn iques in Farm Animal-From Artificial Insemination to Nanobiotechnology. Vet World 2012;5. https://doi.org/10.5455/vetworld.2012.301-310

[4] Colazo MG, Kastelic JP. Reproductive management in cattle and sheep. Encyclopedia of Life Support Systems (EOLSS 2012) Disponível em: http://www eolss net/Sample-Chapters C. 2012;10. https://doi.org/10.1111/j.1742-7843.2011.00688.x

[5] Favareto APA, Fernandez CDB, da Silva DAF, Anselmo-Franci JA, Kempinas WDG. Persistent impairment of testicular histology and sperm motility in adult rats treated with cisplatin at pe ri-puberty. Basic clin pharmacoL 2011;109:85-96. https://doi.org/10.1111/j.17427843.2011.00688.x

[6] Kathiravan MK, Salake AB, Chothe AS, Dudhe PB, Watode RP, Mukta MS, et al. The biology and chemistry of antifungal agents: a review. Bioorgan med chem2012;20:5678-98. https://doi.org/10.1016/j.bmc.2012.04.045

[7] Ali Malayeri F, Rezaei A, Raiesi O. Antifungal agents: Polyene, azole, antimetabolite, other and future agents. J Res Med Sci 2018;5:48-55. https://doi.org/10.29252/jbrms.5.2.48

[8] Brita in RPSoG. Medicines, Ethics, and Practice: A Guide for Pharmacists: Royal Pharmaceutical Society of Great Britain; 2000.

[9] von Heimendahl A, England G, Sheldon I. Influence of Griseofulvin treatment on semen quality in the dog. Anim reprod sci 2004;80:17581. https://doi.org/10.1016/S0378-4320(03)00140-4

[10] Ma Y-M, Ma Z-Q, Gui C-Q, Yao J-S, Sun R-Y. Hepatotoxicity and toxicokinetics of ketoconazole in rabbits. Acta Pharmacol Sin. 2003;24:778-82.

[11] Parker H, McDaniel C. Semen dilution prior to analysis influences the ability of the sperm quality analyzer to predict fertility whether inseminating with a constant number of sperm or a constant volume of semen. Poult sci 2003;82:1808-15. https://doi.org/10.1093/ps/82.11.1808

[12] Habeeb A, Teama F, Nesseim M, Elwan K. Evaluation of Physical Semen Characte ristics of Male Rabbits Exp osed to Different Climatic Condit ions and Lighting Regimes Using Nuclear Techniques. Procee dings of the 9
International Conference for Nuclear Sciences and Applications, ( $p$. 1239). Egypt 2008.

[13] Castro A, Berndtson WE, Cardoso F. Plasma and testicular tes toste rone levels, volume density and number of Leydig cells and spermatogenic efficiency of rabbits. Braz j med biol res 2002;35:493-8. https://doi.org/10.1590/S0100-879X2002000400014

[14] Jezek D, Knuth U, Schulze W. Successful testicular sperm extraction (TESE) in spite of high serum follicle stimulating hormone and azoospermia: correlation between testicular morphology, TESE results, semen analysis and serum hormone values in 103 infertile men. Hum reprod 1998;13:1230-4. https://doi.org/10.1093/humrep/13.5.1230

[15] Ferreira DF. Sisvar: a computer statistical analysis system. Cienc agrotec 2011;35:1039-42. https://doi.org/10.1590/S1413 70542011000600001

[16] Hoffman RR, Shadbolt NR, Burton AM, Klein G. Eliciting knowledge from experts: A methodological analysis. Organizational behavior and human decision processes 1995;62:129-58. https://doi.org/10.1006/obhd.1995.1039

[17] Nashwa A, Kawkab AA, Mouneir SM. The protective effect of ginger and $\mathrm{N}$-acetyl cyste ine on cip rofloxacin-induced reproductive toxicity in male rats. Am J Sci2011;7.

[18] Rochette F, Engelen M, Vanden Bossche $\mathrm{H}$. Antifungal agents of use in animal health-practical applications. J Vet Pharmacol Ther.2003;26:3153. https://doi.org/10.1046/j.1365-2885.2003.00457.x

[19] Kinobe RT, Dercho RA, Vlahakis JZ, Brien JF, Szarek WA, Nakatsu K. Inhibition of the enzymatic activity of heme oxygenases by azole-based antifungal drugs. J Pharmacol Exp Ther 2006;319:277-84. https://doi.org/10.1124/jpet.106.102699

[20] Chanyandura JT. Formulation and evaluation of castro-retentive floating tablet of griseofulvin 2018.

[21] Lionakis MS, Samonis G, Kontoyiann is DP. Endocrine and metabolic manifestations of invasive fungal infections and systemic antifungal treatment. Mayo clin proc: Elsevier; 2008. p. 1046-60. https://doi.org/10.4065/83.9.1046

[22] Othman FM, El-Badry DA, Mohamed MI, Shaker MH, Kotb HR, Torky HA. Efficacy and Safety of Different Antimycotic Formulas Used in Sheep Frozen Semen Extenders. Alex J Vet Sci 2016;48. https://doi.org/10.5455/ajvs. 202266

[23] Adler I-D, Schmid T, Baumgartner A. Induction of ane uploidy in male mouse germ cells detected by the sperm-FISH assay: a review of the present data base. Mutat Res 2002;504:173-82. https://doi. org/10.1016/S0027-5107(02)00090-8

[24] Shin J-H, Moon HJ, Kang IH, Kim TS, Kim IY, Park IS, et al. Repeated 28day oral toxicity study of ketoconazole in rats based on the draft protocol for the "Enhanced OECD Test Guideline No. 407" to detect endocrine effects. Arch Toxicol 2006;80:797-803. https://doi.org/10.1007/s00204-006-0116-y

[25] Deepinder F, Braunstein GD. Drug-ind uced gynecomastia: an evidencebased review. Expert Opin Drug Saf 2012;11:779-95. https://doi.org/10.1517/14740338.2012.712109

[26] Amin A. Ketoconazole-induced testicular damage in rats reduced by Gentiana extract. Exp toxicol pathol 2008;59:377-84. https://doi.org/10.1016/j.etp.2007.10.008

[27] Adams ML, Meyer ER, Cicero TJ. Imidazoles suppress rat tes tosterone secretion and testicular interstitial fluid formation in vivo. Biol reprod 1998;59:248-54. https://doi.org/10.1095/biolreprod59.2.248

[28] Qinghua S, Schmid T, Adler I-D. Griseofulvin-induced aneuploidy and meiotic delay in male mouse germ cells: de tected by using conventional cytogenetics and three-color FISH. Mutat res genet toxicol environ mutagen 1999;441:181-90. https://doi.org/10.1016/S13835718(99)00046-7

[29] Abdelraouf K, Chang K-T, Yin T, Hu M, Tam VH. Uptake of polymyxin B into renal cells. Antimicrob agents chemother 2014;58:4200-2. https://doi.org/10.1128/AAC. 02557-14

[30] Heckman WR, KANE BR, PAKYZ RE, COSENTINO MJ. The effect of ketoconazole on endocrine and reproductive parameters in male mice and rats. J Androl 1992;13:191-8.

[31] Drobnis EZ, Nangia AK. Antimicrobials and Male Reproduction. Impacts of Medications on Male Fertility 2017. p. 131-61. https://doi.org/10.1007/978-3-319-69535-8_10 
[32] Zudova D, Wyrobek AJ, Bishop J, Marchetti F. Impaired fertility in Tstock female mice after superovulation. Rev Reprod 2004;128:573-81. https://doi. org/10.1530/rep.1.00333

[33] Foote RH. Spermicidal effects of amphotericin B and nystatin on bull and rabbit sperm and contraceptive effects in rabbits. Contraception 2002;66:193-7. https://doi.org/10.1016/S0010-7824(02)00347-5
[34] Ciornei Ș, Runceanu L, Drugociu D, Roșca P, Mareș M, Orzan D, et al. The effect of fluconazole addition to boar semen diluents on reproduction parameters. Fungi Mycotoxins 2009;3:267-72.

[35] lamsaard S, Burawat J, Kanla P, Arun S, Sukhorum W, Sripa nidkulchai B, et al. Antioxidant activity and protective effect of Clitoria ternatea flower extract on testicular damage induced by ketoconazole in rats. $J$ zhejiang univ sci 2014;15:548-55. 